\title{
Impact of Mobile Phone Services on the Traditional Telecommunication Services in India
}

\author{
Laveena C. Crasta ${ }^{1,2}$ \& Shailashri V. T. ${ }^{3}$ \\ ${ }^{1}$ Research Scholar, College of Management and Commerce, Srinivas University, Mangalore, \\ India \\ ${ }^{2}$ Assistant Professor, St Aloysius Institute of Management and Information Technology, \\ AIMIT, Mangalore, India \\ Orcid ID: 0000-0003-0481-2156; E-mail: lavishalet@ gmail.com \\ ${ }^{3}$ Research Professor, College of Management and Commerce, Srinivas University \\ Orcid ID: 0000-0002-1684-238X; E-mail: shailashrivt@gmail.com
}

Area of the Paper: Management.

Type of the Paper: Research Case Study

Type of Review: Peer Reviewed as per $|\mathrm{C}| \mathrm{O}|\mathrm{P}| \mathrm{E} \mid$ guidance.

Indexed In: OpenAIRE.

DOI: https://doi.org/10.5281/zenodo.5706597

Google Scholar Citation: IJCSBE

\section{How to Cite this Paper:}

Crasta, Laveena C., \& Shailashri, V. T., (2021). Impact of Mobile Phone Services on the Traditional Telecommunication Services in India. International Journal of Case Studies in Business, IT, and Education (IJCSBE), 5(2), 211-225. DOI: https://doi.org/10.5281/zenodo.5706597

International Journal of Case Studies in Business, IT and Education (IJCSBE)

A Refereed International Journal of Srinivas University, India.

Crossref DOI : https://doi.org/10.47992/IJCSBE.2581.6942.0130

(C) With Authors.

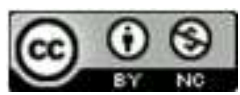

This work is licensed under a Creative Commons Attribution Non-Commercial 4.0 International License subject to proper citation to the publication source of the work.

Disclaimer: The scholarly papers as reviewed and published by the Srinivas Publications (S.P.), India are the views and opinions of their respective authors and are not the views or opinions of the S.P. The S.P. disclaims of any harm or loss caused due to the published content to any party. 


\title{
Impact of Mobile Phone Services on the Traditional Telecommunication Services in India
}

\author{
Laveena C. Crasta ${ }^{1,2}$ \& Shailashri V. T. ${ }^{3}$ \\ ${ }^{1}$ Research Scholar, College of Management and Commerce, Srinivas University, Mangalore, \\ India \\ ${ }^{2}$ Assistant Professor, St Aloysius Institute of Management and Information Technology, \\ AIMIT, Mangalore, India \\ Orcid ID: 0000-0003-0481-2156; E-mail: lavishalet@gmail.com \\ ${ }^{3}$ Research Professor, College of Management and Commerce, Srinivas University \\ Orcid ID: 0000-0002-1684-238X; E-mail: shailashrivt@gmail.com
}

\begin{abstract}
Background/Purpose: Telecommunication is a principal element in the current technologydriven world. The impact of mobile phone services over traditional services is the key to India witnessing the Digital revolution. This paper highlights the mobile phone services that have impacted the traditional services and the digital penetration that has been observed in almost every sector.

Design/Methodology/Approach: This study is mainly based on the data collected from secondary sources of information. The secondary data sources are from annual reports of the telecom sector and websites. It is an explorative research case study that shows the emergence of mobile phone services over traditional telephone services and performs PESTLE analysis.

Findings/Result: Based on the study, India has moved into a digital population to a great extent through the advancements in technology and internet services through data packs and broadband connections. The mobile phone services along with the Telecom sector in India have played a crucial role in this transformation with connectivity, affordability, and technological change.

Originality/Value: This paper analyzes and interprets the data collected from the past 10 years with respect to telecommunications services and mobile services in India. Based on the findings and their interpretation, new knowledge in the form of recommendations/suggestions is presented.
\end{abstract}

Paper Type: Industry Analysis as a Research Case Study.

Keywords: Telecommunication, Mobile phones, Internet services, Digital India, PESTLE analysis.

\section{INTRODUCTION :}

The telecom sector in India has grown in leaps and bounds in the past decade. The telecom sector which had its birth in the 1880s in India has penetrated into many diversified branches due to the technological changes and demands in the market. India today enjoys a subscriber base of 1.17 billion, the 2nd largest in the world. Wired telecommunication had enjoyed the market share for a long time since its inception. It was the introduction of wireless communication that paved a tough competition to the wired communication services. Telephones were considered the proud possession of individuals, but the entry of mobile phones changed the scenario completely. In years to come, telephones probably would be completely replaced by mobile phones. Mobile phone services in India are growing exponentially and contributing substantially to the country's GDP.

\section{RELATED WORKS :}

Mobile phone services are a crucial aspect of an individual's life. They have impacted our day-to-day life to a large extent with the advent of smartphones and internet services. Many authors have contributed to the research work in the area of the telecom sector. Table 1 gives the review of literature in various areas connected to the Telecom sectors and their impact on day-to-day services. 
Table 1: Review of Telecom sector in India

\begin{tabular}{|c|c|c|c|}
\hline S. No. & Area & Issue & Reference \\
\hline 1. & Telecommunication Services & $\begin{array}{l}\text { Open Innovations and Open } \\
\text { Business models }\end{array}$ & $\begin{array}{l}\text { Birudavolu, S. et al. } \\
\text { (2011). [1] }\end{array}$ \\
\hline 2. & $\begin{array}{l}\text { Customer Relationship } \\
\text { Management in Telecom sector }\end{array}$ & $\begin{array}{l}\text { Effectiveness of Mobile } \\
\text { service providers. }\end{array}$ & $\begin{array}{l}\text { Haridasan, V. et al. } \\
\text { (2011).[2] }\end{array}$ \\
\hline 3. & Telecommunication growth & $\begin{array}{l}\text { Analysis of the factors } \\
\text { influencing Telecom Growth } \\
\text { case study of India and China }\end{array}$ & $\begin{array}{l}\text { Venkatram, R. et al. } \\
\text { (2012). [3] }\end{array}$ \\
\hline 4. & Telecom industry. & $\begin{array}{l}\text { Customer satisfaction in the } \\
\text { Telecom industry }\end{array}$ & $\begin{array}{l}\text { Popli, G. S. et al. } \\
\text { (2013). [4] }\end{array}$ \\
\hline 5. & Telecommunications & $\begin{array}{l}\text { Problems and reforms of the } \\
\text { telecom sector in India. }\end{array}$ & Gupta, S., (2015). [5] \\
\hline 6. & Telecom service providers & $\begin{array}{l}\text { Factors leading to adoption of } \\
\text { Over the Top (OTT) services. }\end{array}$ & $\begin{array}{l}\text { Sujata, J. et al. (2015). } \\
\text { [6] }\end{array}$ \\
\hline 7. & $\begin{array}{l}\text { Impact of technology on the } \\
\text { Telecom sector in India }\end{array}$ & $\begin{array}{l}\text { Influence of technological } \\
\text { advancement on the Telecom } \\
\text { sector and the Business model } \\
\text { that needs to be in power with } \\
\text { the changes. }\end{array}$ & $\begin{array}{l}\text { Yadav, K. et al. } \\
\text { (2015). [7] }\end{array}$ \\
\hline 8. & Growth of Telecom sector & $\begin{array}{l}\text { Evaluation of Indian Telecom } \\
\text { sector's performance and } \\
\text { analyzing the determinants that } \\
\text { influences it. }\end{array}$ & Jatav. A., (2016) [8] \\
\hline 9. & Tele & $\begin{array}{l}\text { The trends, opportunities and } \\
\text { risks on the Telcom services. }\end{array}$ & $\begin{array}{l}\text { Ukkaravel, V. et al. } \\
\text { (2016). [9] }\end{array}$ \\
\hline 10. & ctor in India & $\begin{array}{l}\text { Evaluating the evolution \& } \\
\text { challenges of the telecom } \\
\text { sector. }\end{array}$ & Deo, A., (2017). [10] \\
\hline 11. & Telecom service in India & $\begin{array}{l}\text { Progress of Telecom sectors } \\
\text { and its services. }\end{array}$ & $\begin{array}{l}\text { MuthuKrishnaveni, } \\
\text { R., (2017). [11] }\end{array}$ \\
\hline 12. & $\begin{array}{l}\text { Telecom sector, quality of } \\
\text { service }\end{array}$ & $\begin{array}{l}\text { Customer expectation and } \\
\text { satisfaction of services } \\
\text { provided by telecom sector. }\end{array}$ & $\begin{array}{l}\text { Sharma, P. et al. } \\
\text { (2017). [12] }\end{array}$ \\
\hline 13. & $\begin{array}{l}\text { PEST analysis of the Telecom } \\
\text { sector }\end{array}$ & $\begin{array}{l}\text { To understand the political, } \\
\text { economic, social and } \\
\text { technological factors that } \\
\text { influence the Telecom sector } \\
\text { in India. }\end{array}$ & $\begin{array}{l}\text { Sravanth, K. R. S. et } \\
\text { al. (2019). [13] }\end{array}$ \\
\hline 14. & Telecom Industry in India & $\begin{array}{l}\text { Assessment of the telecom } \\
\text { operators and the stress in the } \\
\text { industry. }\end{array}$ & $\begin{array}{l}\text { Agarwal, A. et al. } \\
\text { (2021). [14] }\end{array}$ \\
\hline
\end{tabular}

\section{OBJECTIVES :}

The objectives of this study are stated as follows.

(1) To study the growth of the Telecom sector in India.

(2) To understand the penetration of mobile phone service in the telecommunication sector in India.

(3) To study the effects and factors that have impacted the mobile services growth in India.

(4) To study the impact of mobile services over traditional services in India.

(5) To perform PESTLE analysis of the Telecom sector in India. 


\section{METHODOLOGY :}

The data here is collected from secondary sources of information. It is majorly taken from the annual reports, research publications \& websites by considering the past decade. The data collected is wellsummarized and used to show the effectiveness of the study.

\section{OVERVIEW OF THE TELECOM SECTOR IN INDIA :}

Telecommunication is a major essence of human communication. It is the transmission of information over a considerable distance. Information can be in the form of voice messages, signs, images that are transmitted through radio, optical or any other electromagnetic system. The major components of the telecom sector are the telephone, the internet, and television. The telecom sector in India has seen a great transition from a wired connection to a wireless one that dominates the Telecom sector today. The early communication system used visual signals, but over the years communication has evolved through electrical devices. Today, communication takes place through fiber optics and instruments that provide voice, data, and broadband services. The introduction of mobile services in the telecom sector has witnessed a great impact on traditional wired communication services. Mobile phone services that took their birth in 1995 in India have nearly replaced all the traditional telecommunication services.

\section{THE GROWTH OF THE TELECOM SECTOR IN INDIA :}

Early communication services were initiated by the postal department through the telegraph in the year 1851. The postal and telecom sector were closely related and were considered one of the world's oldest communication services. The traditional communication services comprised the telephone and telegraph until they were separated in 1975. Early telecommunication in India dates back to 1881 when England opened telephone exchanges in Kolkata, Mumbai, and Chennai. The first telephone service began in the year 1882 with 93 subscribers. Communication gained its momentum by rolling from cable telegraph to wireless telegraph, radiotelegraph, radiotelephone, and trunk dialing. In the initial stages, the functions of telecommunication operations were managed by the public works department (PWD), then transferred to the Director-General Postal and Telegraph (DGP \& T), then moved to the Department of Telecommunication (DoT) and last was in the hands of Bharath Sanchar Nigam Limited (BSNL). The Indian telecom sector has seen tremendous growth in the past decade. The major milestones are summed up in table 2 .

Table 2: Path of success

\begin{tabular}{|l|l|}
\hline Year & \multicolumn{1}{|c|}{ Milestones } \\
\hline 1851 & Operational Telephones lines deployed between Kolkata and Diamond Harbour. \\
\hline 1881 & Commencement of Telephone service in India \\
\hline 1882 & Beginning of the First telephone exchange in Kolkata, Chennai and Mumbai \\
\hline 1883 & Unification of telecommunication with postal system \\
\hline 1902 & First Telegraph Station established \\
\hline 1923 & Introduction to Indian Radio Telegraph Company \\
\hline 1947 & $\begin{array}{l}\text { Unification of the Postal services, Telephone services and Telegraph under Government's } \\
\text { Ministry of Communications }\end{array}$ \\
\hline 1960 & First Subscriber Trunk Dialing (STD) services established between Kanpur and Lucknow \\
\hline 1975 & $\begin{array}{l}\text { Telecommunication and Postal services split up and a separate department of } \\
\text { telecommunication (DoT) is established }\end{array}$ \\
\hline 1985 & Mobile service introduced in Delhi on non-commercial basis \\
\hline 1994 & National Telecom Policy introduced by the Government. \\
\hline 1995 & Commercialization of the cellular services in India \\
\hline 1997 & Formation of the Telecom Regulatory Authority (TRAI) \\
\hline 1999 & Introduction of the new telecom policy (NTP 1999). \\
\hline 2000 & National long-distance market (NLD) was opened up to the private sector. \\
\hline 2002 & Bharati Airtel makes its way into BSE \& NSE. \\
\hline 2003 & Internet and GPRS launched through cellular services. \\
\hline 2004 & Announcement of Broadband policy. \\
\hline
\end{tabular}


2005 FDI raise to 74\% in the telecom sector. Manufacturing mobile phones by Motorola in India. New schemes of lifetime validity on prepaid unveiled.

2006 India entered the 00 million mobile subscribers club and in August 2006 overtook China to achieve the target of fastest growing telecom market in the world.

2007 Roaming rental was reduced to zero. Indus Towers was formed by Airtel, Vodafone and Idea.

2009 India marked 500 million mobile subscriber market with Airtel crossing its 100 million subscriber marks.

2010 Mobile subscriber numbers crossed 650 million. Reliance launched its broadband services through acquisition of Infotel broadband services limited [15].

2018 Merger of Telnor India with Bharti Airtel. Merger of Vodafone with Idea known by VI

2020 celebration of 25 years of Mobility

Source: Path of success [16]

\section{TRADITIONAL SERVICES AND IMPACT OF MOBILE SERVICES :}

\subsection{Wired communication:}

The telephone is the oldest form of wired telecommunication which in recent years has been losing its charm due to the tremendous growth of mobile services. Wired telecommunication connection, which was at one time considered to be a proud possession, has now been replaced by wireless mobiles. BSNL and MTNL were the only fixed-line telephone providers until cellular services entered the Indian market. BSNL was the pioneer in telecommunication services. Later on Airtel, Jio, and VI also entered the race. The entry of cellular services brought in tough competition to the landline service providers so as to provide efficient and quality services to their subscribers in order to sustain themselves. Table 3 and Fig. 1 show the downward trend of the telephone or wired telecom subscribers. Mobile phones are preferred over the telephone due to varied factors like mobility, tariffs, digitization of services, and wider coverage.

Table 3: Telephone subscribers in India

\begin{tabular}{|c|c|}
\hline Financial year & $\begin{array}{c}\text { Number of telephone } \\
\text { subscribers }\end{array}$ \\
\hline 2011 & 34.73 million \\
\hline 2012 & 32.17 million \\
\hline 2013 & 30.21 million \\
\hline 2014 & 28.50 million \\
\hline 2015 & 26.59 million \\
\hline 2016 & 25.22 million \\
\hline 2017 & 24.40 million \\
\hline 2018 & 22.81 million \\
\hline 2019 & 21.70 million \\
\hline 2020 & 19.13 million \\
\hline
\end{tabular}

Source: TRAI - Annual reports [17] 


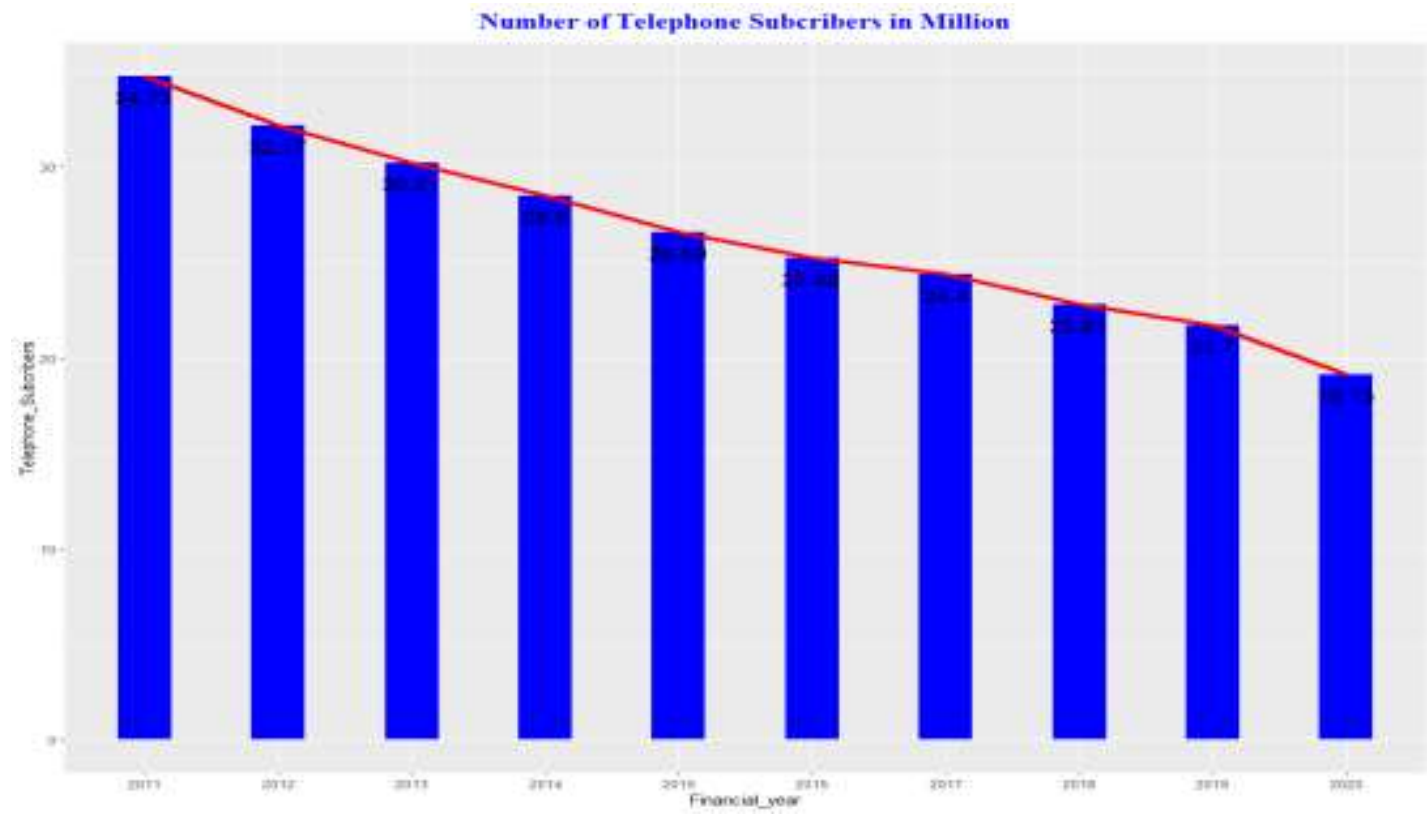

Fig. 1: Telephone Subscribers in million [17]

\subsection{Wireless communication:}

Pager \& Mobile communication: The mobile and pager services entered the Indian market simultaneously in the year 1995. The pager brands were majorly associated with Motorola, Philips, and Casio. Pagers soon picked the market as they were small in size, had good battery life, and were available at an affordable price. The option of call forwarding to a pager from the fixed phone connection was well-appreciated in the market. However, the Pager services didn't survive in the Indian market for long as they could not sustain themselves. The year 2002 marked a steady decline in the number of subscribers to pager services and soon thereafter it completely disappeared from the Indian market. Mobile phones were quite expensive, not just the device but also the charges of incoming and outgoing calls. India initially had the Receiving Party Pays (RPP) system and then moved into Calling Party Pays (CPP) system which brought in more subscribers. Mobile phones soon took over the market due to the portability and technological changes that took place on a regular basis. The present Telecom sector is ruled by mobile phone services as they provide wide coverage, affordable tariffs, and datadriven applications that have forced the subscribers into the digital mode. Mobile phones have captivated and dived deep into the life of every person that is inseparable. Individuals today are in constant search of better connectivity and hence the network providers often see that customers are shifting from one network to the other. The survival of the network in the present scenario highly depends on how best it can offer its services to subscribers. Mobile services took over the market at a great speed not just due to their mobility but also due to the good tariffs of the service providers. The last decade has seen a transformation in the field of wireless communication. This transformation is a combination of mobility, the internet, and mobile handsets. The technological changes and advancements have been a key trait in order to move towards wireless communications with every aspect plugged into one device. Mobile Number Portability (MNP), a telecom revolution was launched in India in the year 2011, a key feature that helps people to move from one network to the other without changing their contact number

Internet / Broadband: The internet era in India had its beginning in the year 1995. VSNL was the first internet service provider. It took a decade when internet usage bloomed, and India saw exponential growth since then. The tremendous growth can be attributed to the change in government policies, the speed of the internet, competition among public and private service providers. According to the Annual Report of Nokia India, Nokia India is ranked second in broadband usage on mobile phones in the world [10]. Telecommunication has seen a drastic change of moving into the online mode due to the high flexibility and quick access without any geographical limitations. This has helped people to stay connected with their loved ones who are dispersed in any part of the world [14]. Broadband services have played a key role in video calls which creates more sentiments and closeness to family and friends. 
COVID 19 has bought more technological advancements to improve communication through online platforms like Google Meet, Microsoft Teams, Zoom, and many others which are highly and solely dependent on the internet or broadband services. Table 4 and Fig. 2 depict the growth in the internet subscribers.

Table 4: Internet subscribers in India

\begin{tabular}{|c|c|}
\hline $\begin{array}{c}\text { Financial } \\
\text { year }\end{array}$ & $\begin{array}{c}\text { Number of internet } \\
\text { subscribers }\end{array}$ \\
\hline 2011 & 19.67 million \\
\hline 2012 & 22.86 million \\
\hline 2013 & 21.61 million \\
\hline 2014 & 251.59 million \\
\hline 2015 & 302.35 million \\
\hline 2016 & 342.65 million \\
\hline 2017 & 422.20 million \\
\hline 2018 & 493.96 million \\
\hline 2019 & 636.73 million \\
\hline 2020 & 743.19 million \\
\hline
\end{tabular}

Source: TRAI - Annual reports [17]

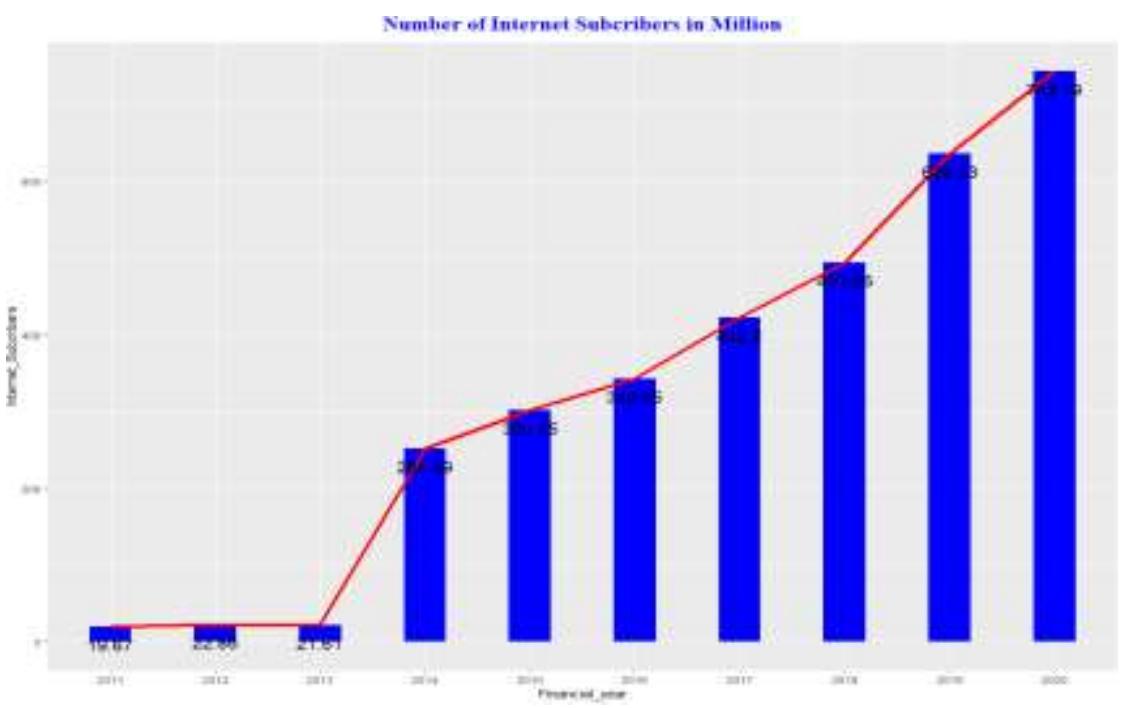

Fig. 2: Internet Subscribers in million [17]

\subsection{Impact of Mobile services:}

The advancement in the field of mobile phones is the key element that is instrumental in the digital revolution in India. Smartphones and $4 G$ technology are the driving force that has influenced the government and individuals to move towards e-governance, e-education, e-health, online transactions, e-commerce, and so on. Table 5 shows the tremendous growth in the number of mobile subscribers that can be attributed to the reason for the digital revolution in India. We have witnessed a great change in the education system due to COVID 19, which has forced education to move into online mode. This can be seen as a breakthrough that India needed in order to significantly affect the literacy rates in rural areas. The government of India has taken up many initiatives towards the digitalization of the education system [18]. The wireless communication of the Telecom sector with its infrastructure, connectivity, and affordability can make this dream come true. India has penetrated into providing a lot of government services online, which has created a better relationship between the government and its citizens. India has witnessed a great surge in the percentage of digital literacy which has influenced the digital revolution. The education system has been highly influenced by the advances in technology [19] and services of the telecom sector through broadband and data packs enabling the effective use of online educational platforms [20]. India today has 624 million active internet users with an e-commerce penetration of $76.7 \%$ that can be attributed to the exponential demand for smartphones [4]. Mobile phones today are not just an instrument for one-to-one communication but have a large variety of 
applications that help people to gain better services from various sectors. As of February 2021, Fig. 3 shows the growth in the millions of digital populations of India via data packs and broadband.

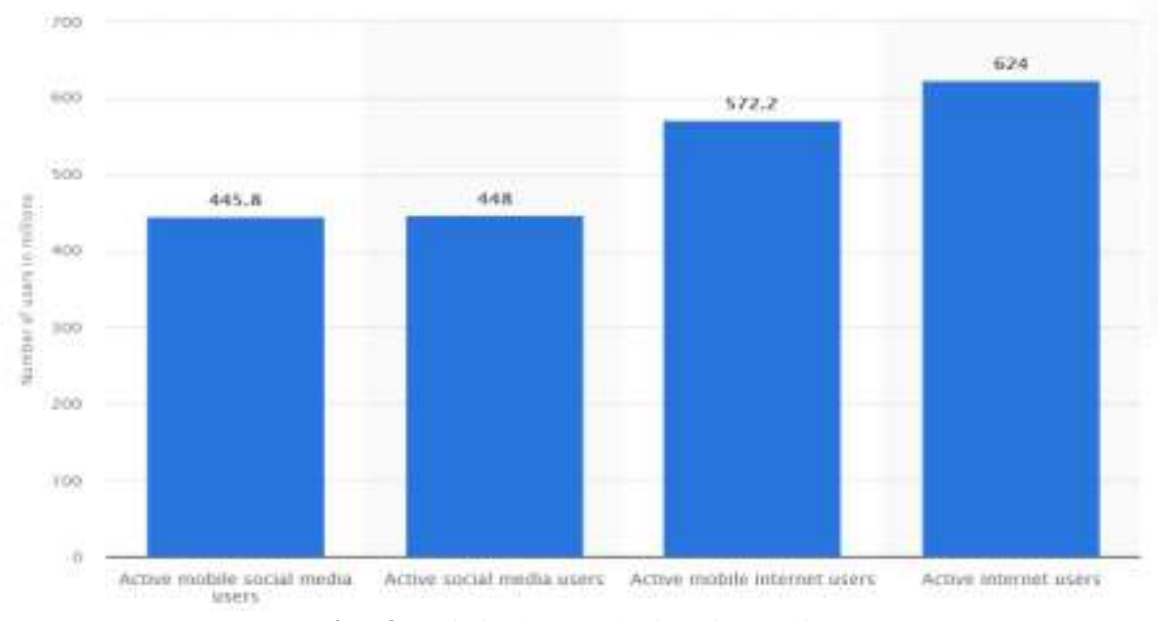

Fig. 3: Digital population in India

Source: Digital population of India [21]

2020 had witnessed 150 million online shoppers compared to that of 135 million in 2019, the number is bound to be larger by the end of 2021. The growth can be credited to the growing e-commerce as well as the COVID-19 pandemic that has influenced the shopping behavior among consumers. The trend towards online shopping is exponentially growing owing to the flexibility of being able to shop from anywhere, anytime, and being able to choose from a large variety of products [20]. The rate of growth which is depicted in Fig. 4 shows that India will soon be dominated by online shoppers replacing the traditional way of shopping. The main driver of online shopping mode is internet access through mobile devices and laptops. As online shopping is turning out to be the preferred way of shopping over the traditional one, the telecom sector services need to be at their best in making this experience the wonderful one [22] [23]. The online mode of shopping is a multi-party activity that has interconnection with customers, suppliers, financial institutions, delivery personnel who are a part of the stages of purchasing [24]. Table 5 and Fig. 5 are giving the statistics showing the impact that mobile phone services have created with the number subscribers growing at a faster rate.

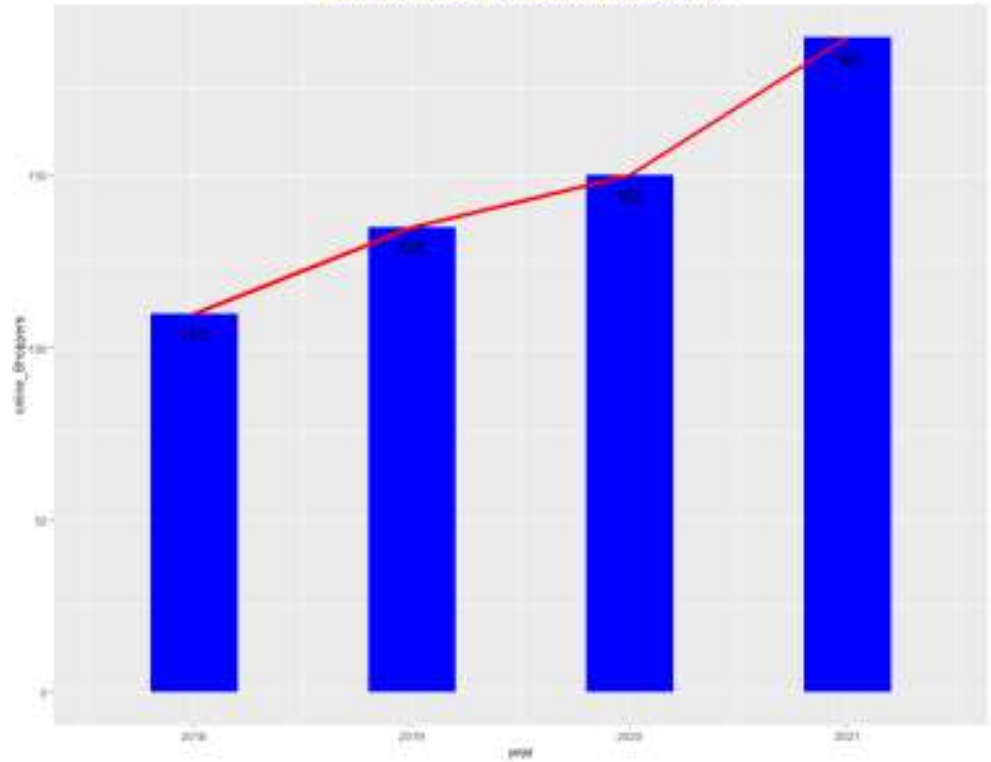

Fig. 4: Annual online Shoppers in India in millions

Source: Annual online shoppers in India [25] 
International Journal of Case Studies in Business, IT, and Education (IJCSBE), ISSN: 2581-6942, Vol. 5, No. 2, November 2021

Table 5: Mobile subscribers in India

\begin{tabular}{|c|c|}
\hline $\begin{array}{c}\text { Financial } \\
\text { year }\end{array}$ & $\begin{array}{c}\text { Number of mobile } \\
\text { subscribers }\end{array}$ \\
\hline 2011 & 811.59 million \\
\hline 2012 & 919.97 million \\
\hline 2013 & 867.80 million \\
\hline 2014 & 904.52 million \\
\hline 2015 & 969.54 million \\
\hline 2016 & 1034.11 million \\
\hline 2017 & 1170.59 million \\
\hline 2018 & 1188.99 million \\
\hline 2019 & 1161.71 million \\
\hline 2020 & 1157.66 million \\
\hline
\end{tabular}

Source: TRAI - Annual reports [17]

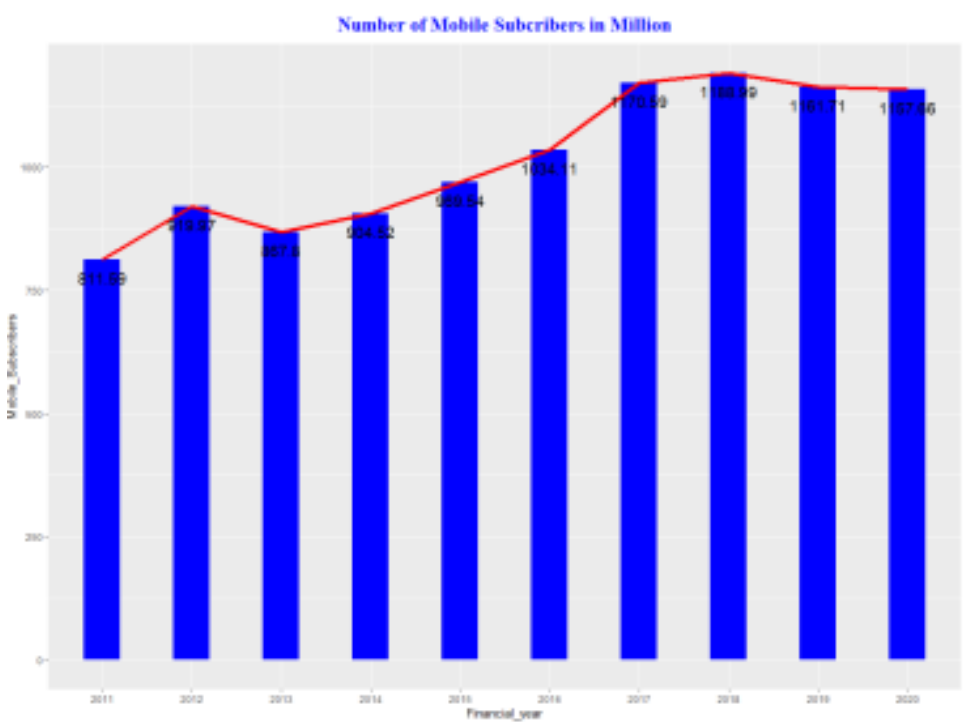

Fig. 5: Mobile Subscribers in million

8. PESTLE ANALYSIS OF THE TELECOM INDUSTRY IN INDIA :

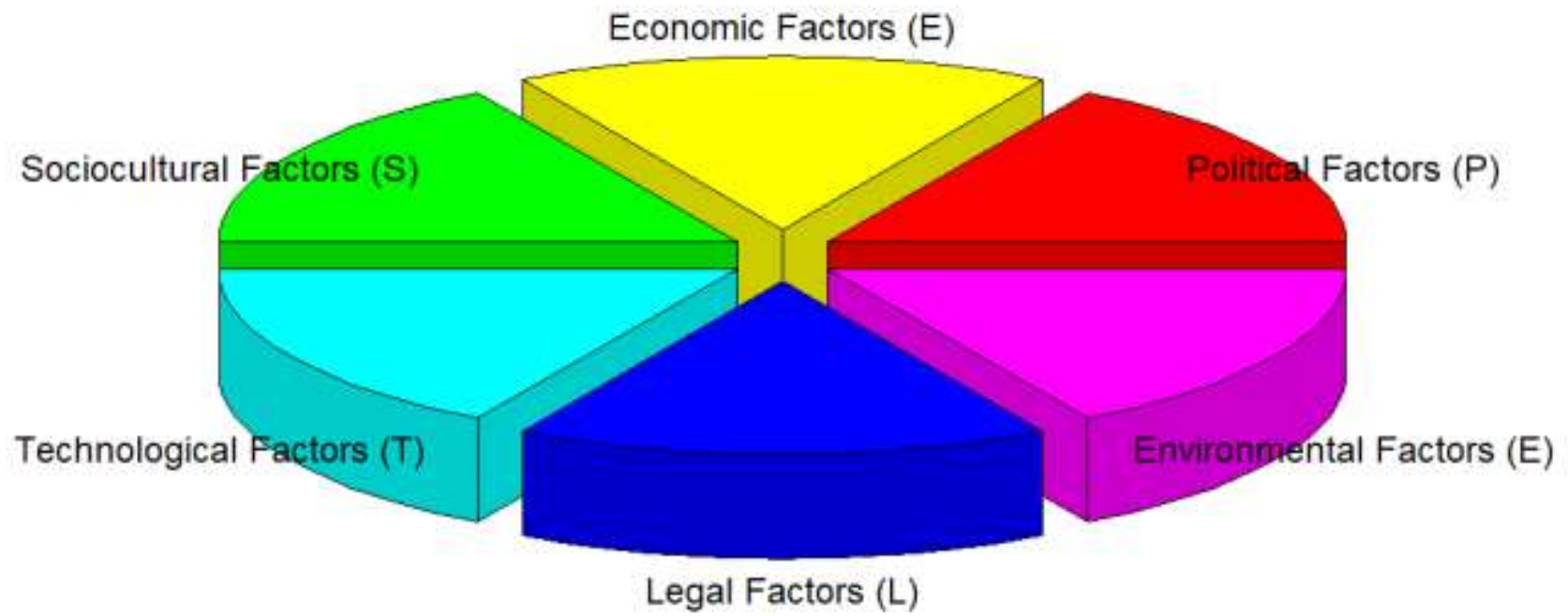

Fig. 6: Components of the PESTLE analysis 


\subsection{Political factors:}

Political factors play a vital role in the growth of any industry. They are the driving force contributing directly or indirectly towards the better performance of an industry. India has brought in various reforms and is adopting policies and regulations that will help the Telecom sector to have the largest penetration. India has introduced several policies that have been instrumental in boosting the overall development of the Telecom sector.

The liberalization policies that were introduced in the year 1991 paved the way for private companies to enter the Telecom sector. This resulted in incremental growth and competition in the market. The rise in competition has been very favorable to the subscribers as the tariffs were decreased. The telecom industry today is well-equipped and is contributing to the country's growth with a great magnitude.

The National Telecom Policy 1999: This aimed at increasing the telephone subscribers by developing the rural areas through affordable tariff structure. It is also aimed at improving internet access, infrastructure, and speed in order to promote more accessibility to subscribers [26].

National broadband policy 2004: The main goal of this policy is to implement smooth functioning of egovernance to all the citizens by providing high speed, low-cost broadband, and Telecom infrastructure [27].

National Telecom policy 2012: The policy strives at stressing the importance of Broadband penetration and its impact on the country's GDP. With this motive, the policy strives to empower an inclusive knowledge-based society so as to provide comprehensive growth [28].

National Digital Communications Policy 2018: This policy aims towards digital empowerment of the economy and society. It is more customer-focused and application-driven leading to newer ideas and innovation. The policy aims to create a data protection regime for safeguarding privacy, autonomy, and choice of an individual's digital communication [29].

Foreign Direct Investments (FDI's): FDI has influenced the Telecom sector towards building the infrastructure and empowering financial expansions. The financial year 2020 witnessed US $\$ 4.4$ million in FDI. This was a good comeback after India witnessed a decline in FDI in the financial year 2019.

National policy on education 2020: The policy tends to move towards a technologically driven education system that paves the way to a modern, futuristic and creative educational system. The policy strives to have great reachability of education to rural and urban India.

\subsection{Economic factors:}

The telecommunication sector has been a forerunner in contributing largely to the economic growth of India. There is a direct and indirect impact of telecommunication sector, especially the wireless communication in the economic growth of the country. The increase in the teledensity will have a direct impact on employment and revenue [30]. The enormous growth experienced in the telecom sector should definitely increase its revenue and in turn benefit the economic growth of the country. However, the intense market competition is not helping the same as tariff acts as a major catalyst to attract more subscribers which needs to be at a lower rate [3]. The situation is bound to change in India as the number of service providers have drastically decreased. Telecom Regulatory Authority of Indic (TRAI) has always been the backbone that supports initiatives to foster growth of the telecom sector. India emerging as a global information society is a result of the TRAI's initiatives to improvise on the telecommunication, broadcasting and cable sectors. TRAI has been a key player that has enabled the applications like Aadhar, e-governance, e-commerce, e-health, e-education and e-trade. Telecom sector provides services that help the citizens in their crucial day to day need of important sectors of economy. Banking today is highly dependent on the telecom services and has reached to a larger sector by providing easy and quick access to their service through mobile applications. With major service sectors moving into the digital space, the telecom sector will definitely have a great impact on the economic growth of the country [31].

\subsection{Sociocultural factors:}

Advancement in the field of technology has always had a direct impact on society. Telephones, the wired mode of communication was an important aspect of an individual to maintain cordial relationships among loved ones. It paved the way of being connected through a call to people from any part of the world. The advent of mobile phones, especially the nature of portability, has made the mobile phone one of the organs of the human body. Mobile phones have become an inseparable element of an individual's life. It has defined a new mode of communication with people from all over the world through various social media and instant messaging applications. Telecommunication today is not just 
audio, but a combination of audio and visual that adds more bonding to a relationship. Through the pandemic, COVID-19 relationships have been nurtured through the service of the telecom sector through the internet and mobile phones. Mobile phones today have created obsession among the younger generation that can be seen as a threat and an advantage as they are exposed to people from all over the world. The information which at one point in time was considered to be private is now turning into public display. The very definition of culture is completely changed, today connectivity is a new culture [32]. There were times when mobile phone usage was considered taboo at workplaces and places of worship, but now it is no longer considered so [33]. Our culture is being driven by the concept of mobile phones where phone numbers play a vital role than the person itself [33]. The telecom sector has given a new dimension towards fun and business through the online mode [34]. The social physical interactions that helped in getting to know people have been drastically affected. Mobile phones have greatly impacted the social interaction which today is more of text messages and mobile calls giving a new perspective to the social environment. Today social interactions take place with people from any part of the world through online mode overcoming the barriers of time and space [35]. Children today are more concerned about their virtual friends than the people who are the part of their physical family [36].

\subsection{Technological factors:}

The technology and the telecom sector are interrelated as both of them move hand in hand in the development of the Telecom sector. Today we see the telecom sector as a very technical industry that is in a constant move to provide quality communication. The smartphone penetration in India has grown to $60.63 \%$ in 2021 . There is an exponential growth in the level of penetration and the speculation is that India will reach $95 \%$ of smartphone penetration by the year 2040 [3], [37]. India has completely moved into the 4th generation of telecommunication technology or $4 \mathrm{G}$ with nearly $99 \%$ of mobile subscribers moving into online mode. The $4 \mathrm{G}$ service was the driving force to lead the country's digital revolution. The advent of $5 \mathrm{G}$ services will definitely have the country move to a totally technologically driven society with the applications such as artificial intelligence, quantum computing, virtual reality, etc. ruling the market. These changes in technology will have a direct impact on the telecom sector which will hold the key in making it a reality [7]. Telecom equipment manufacturing in India is a great challenge due to high logistics costs, undependable power supply, and high competition from Chinese low-cost equipment. The world today is moving into auto-driven vehicles which are heavily dependent on the technology and telecom sector in order to provide the best and safe driving experience. The emergence of Biometrics in mobile phones, IoT, Smart homes, smart cities is all thriving on connectivity as their core component. This shows that technological factors or changes will play a vital role in the Telecommunication sector [7]. These advancements in the technological arena are directly proportional to the profitability of the telecom sector. Technology and telecom driven sectors like Egovernance aims to have speeder services at low cost and time effectiveness to empower citizens by providing easy access to government services through broadband services. The transition into digitalization has created a high dependency on the internet or broadband services in an individual's day-to-day life. The telecom sector is a key player in the process of digital India and contributes largely towards e-Governance in crucial areas such as health, education, skill development, employment, and banking. This increases the accountability on the part of the government and fosters a better relationship between citizens and the government. The importance of e-governance was very much felt and appreciated due to COVID-19. The majority of the service sectors in India switched over to online mode that was highly dependent on the telecommunication sector in providing essential service to the citizens. Work-from-home was carried out effectively through the internet services through good connectivity.

8.4.1 e-Education: COVID-19 has forced our education system to be more of a blended form. It has given a new horizon with respect to online teaching and learning system. According to an Oxford report, it states that "India did well in the transition to digital learning" [38]. This move indicates that the Telecom sector is having greater reachability through the internet in order to meet the social need for education. It is also important now to have a good service put in place not only in urban India but especially in rural India. Educating young minds online has definitely an advantage of higher reachability of educating young minds all over India. The internet access, affordability, and infrastructure of the Telecom sector are the driving force for the future of digital learning. India can improve its literacy rate by empowering the telecommunication sector through the right policies and also have a boost in the country's GDP. 
8.4.2 e-Health: Health care is the need of the hour, and its transition into the digital arena has increased the demand for broadband or internet services. The inclination of health towards digital mode is a very crucial area that forces the telecom sector to be at its best in delivering uninterrupted broadband services so as to have better reachability. This empowers the health management information system to keep track of every individual's information [39]. Telemedicine has witnessed a considerable amount of increase in the last decade and is expected to grow gradually in the years to come [40].

8.4.3 Rural development: The development of rural India largely depends on the broadband penetration rate in rural areas. This in turn educates rural India to move into the digital model by using various facilities. The government has implemented e-service in the agriculture sector as well as to have easy access through E-Panchayat, farmer's Portal, fertilizer monitoring system, Kisan Suvidha, Pusa Krishi, m-kisan \& Soil health card [39].

\subsection{Legal factors:}

The TRAI frames regulatory reforms that help in implementing various regulations that are the driving force in ensuring technical compatibility and functional interconnection among service providers. TRAI ensures the compliance of terms and conditions in the license. All legal aspects of the telecom sector are governed by the Telecom regulatory authority of India. The TRAI transparency in exercising power and functioning appropriately plays a key role in the performance of the Telecom sector. The authority aims at ensuring the growth of the Telecom sector and protecting the interests of the subscribers. TRAI has been instrumental through the amendment of the TRAI act in 2000 to notify the Official Gazette of the rates of calls and messages within and outside India. It keeps a check on the rates at which service providers provide the necessary services to their customers. Mobile phones have brought an evolution in the social behavior among individuals.

\subsection{Environmental factors:}

E-waste the collection of electrical and electronic equipment is essential factor that needs to be considered as it could lead to environmental pollution and health hazards. Efficient e-waste management is very much required to have a good environment performance index. India ranks at number 5 among the e-waste producing countries in the world [41]. If this is not well-managed, it could lead to contamination of water sources and health care could be at stake [42]. Appropriate recycling of e-waste can have significant economic potential. India has e-Waste rules 2016, which were later amended in 2018 to facilitate and effectively implement eco-friendly e-waste management. Inappropriate disposal of e-waste can lead to climate change as a result of the chemical released when burnt. E-waste is a serious problem that can harm human life and environment as a whole. The telecommunication service providers, electronic manufacturing companies along with the end users need have a consensus on how to effectively manage e-waste.

\section{RECOMMENDATIONS :}

In the present technology-driven world there exists a great extent of interrelationships between several industries. The telephone, mobile, equipment manufacturing sector and many others are highly dependent on each other to sustain themselves in a market that is growing at great speed never seen before. These sectors are facing great challenges with respect to the global trends, rapidly changing technologies and intense competitiveness along with the political and regulatory frameworks. The Telecom sector needs to improvise on its infrastructure so as to have greater reachability to every citizen of India with ease in order to gain services of various sectors. As we move into the digital arena in almost all sectors, it is important that the major driving force, the internet service, will be crucial in the realization of digital India.

\section{CONCLUSION :}

Based on the study, meaningful insights have been gained that throw light on the growth and importance of mobile phone services. The Internet plays a key role in observing the major impact that mobile phone services have been achieved over the traditional wired telephone services. Smartphones driven with data packs and applications that moved the key service sectors into an individual through one-touch mode are the key to the digital revolution, and this penetration will see its peak in the near future. The telecom sector has a major role to play in every sector as it is the backbone of digital India. The quality of service, connectivity, affordable data packs, and interconnection among the intertwined industries are the key to the impact that mobile phone services have witnessed. 


\section{REFERENCES :}

[1] Birudavolu, S., \& Nag, B. (2011). A study of open innovation in telecommunication services: A review of literature \& trends. IIFT Working Paper Series, No. EC-11-09.

Google Scholar $x^{\nearrow} \quad$ CrossRef $x^{\top}$

[2] Haridasan, V., \& Venkatesh, S. (2011). CRM implementation in Indian telecom industryevaluating the effectiveness of mobile service providers using data envelopment analysis. International Journal of Business Research and Management, 2(3), 110-127.

Google Scholar $\not$ CrossRef

[3] Venkatram, R., \& Zhu, X. (2012). An analysis of Factors Influencing the Telecommunication Industry Growth: A case study of China and India (Dissertation). http://urn.kb.se/resolve?urn=urn:nbn:se:bth-2090. Accessed on September 20, 2021.

Google Scholar $\chi^{\nearrow} \quad$ CrossRef

[4] Popli, G. S., \& Madan, D. (2013). Determinants of Customer Satisfaction in Telecom IndustryA Study of Indian Telecom Industry. Available at SSRN 2277570.

Google Scholar $\chi^{\nearrow} \quad$ CrossRef $x^{\nearrow}$

[5] Gupta, S. (2015). Telecommunications at the crossroads in India. IIMB Management Review, 27(3), 196-208.

Google Scholar Х

$\underline{\text { CrossRef } X^{\top}}$

[6] Sujata, J., Sohag, S., Tanu, D., Chintan, D., Shubham, P., \& Sumit, G. (2015). Impact of over the top (OTT) services on telecom service providers. Indian Journal of Science and Technology, $8(\mathrm{~S} 4), 145-160$.

Google Scholar $\chi \quad$ CrossRef $ヌ$

[7] Yadav, K., Tiwari, S., \& Divekar, R. (2015). Impact of technological changes in telecom sector in India. Indian Journal of Science and Technology, 8(S4), 194-199.

Google Scholar $X^{\searrow} \quad \underline{\text { CrossRef }} x^{\top}$

[8] Jatav, A. (2016). Determinants of Growth of Indian Telecom Industry, International Journal of Research in Humanities \& Soc. Sciences, 4(7), 6-12.

Google Scholar $\chi^{\top} \quad$ CrossRef

[9] Ukkaravel, V., \& Gunaseelan, S. (2016). Telecom services: emerging trends, opportunities and risk. Splint International Journal of Professionals, 3(10), 121.

Google Scholar $\chi^{\top} \quad$ CrossRef

[10] Deo, A. (2017). Telecom Industry in India: Evolution, Current Challenges \& Future Road Map. Indira Management Review, 11(1), 92-105.

Google Scholar $\chi^{\nearrow} \quad$ CrossRef

[11] MuthuKrishnaveni, R. (2018). A Study on Telecom Service in India. Research Explorer, 6(20), $1-3$.

Google Scholar $\chi^{\nwarrow} \quad$ CrossRef

[12] Sharma, P., \& Jhamb, D. (2017). Measuring service quality in the telecom industry in India. International Journal of Management Studies, 4, 123-131.

Google Scholar $\chi^{\nearrow} \quad$ CrossRef

[13] Sravanth, K. R. S., Sundaram, N., \& Kannaiah, D. (2019). PEST analysis of present indian telecom sector. International Journal of Innovative Technology and Exploring Engineering, 9(2), 4938-4942.

Google Scholar $\chi^{\top} \quad \underline{\text { CrossRef }} \chi^{\top}$

[14] Agarwal, A., Sharma, K., \& Ramanan, V. (2021). Assessment of Telecom Industry in India-From 2007 to 2020. Asian Journal of Economics, Finance and Management, 18-33.

Google Scholar $\chi^{\nearrow} \quad$ CrossRef 
[15] Suchetha Vijayakumar, \& Nethravathi P. S. (2021). The Growth of IT \&amp; BPM Industry Services and its Journey towards 'Make in India' - A Case Study. International Journal of Case Studies in Business, IT and Education (IJCSBE), 5(1), 232-243.

Google Scholar $\chi^{\top} \quad$ CrossRef ${ }^{\nearrow}$

[16] Telecommunication in India. https://en.wikipedia.org/wiki/Telecommunications in India. Accessed on July 17, 2021.

[17] TRAI- Annnual Reports. https://www.trai.gov.in/about-us/annual-reports. Accessed on August 3,2021 .

[18] Hebbar, C. K. (2020). Impact of Digital India on Education System. International Journal of Case Studies in Business, IT and Education (IJCSBE), 4(2), 65-70.

Google Scholar 7 CrossRef $\not$

[19] Pinto, Severine., \& Lourdusamy, A. (2021). Technology as an Elixir to the Future of Education: Impact on the Traditional Modes of Teaching. International Journal of Case Studies in Business, IT and Education (IJCSBE), 5(1), 221-231.

Google Scholar $\chi^{\nearrow \quad \text { CrossRef } \chi^{\nearrow}}$

[20] Geetha Poornima, K., Vinayachandra, R. M., \& Krishna Prasad, K. (2021). The Effect of Integration of Different Online Education Methods on Educational Advancement and Student Development: A Study. International Journal of Case Studies in Business, IT and Education (IJCSBE), 5(1), 200-220.

Google Scholar $\chi^{\nearrow}$

CrossRef $\not 2$

[21] India Digital population. https://www.statista.com/statistics/309866/india-digital-population/. Accessed on September 22, 2021.

[22] e-commerce in India. https://www.statista.com/topics/2454/e-commerce-in-india/. Accessed on September 22,2021.

[23] Goyal, A. (2015). Rising trends of online shopping in India. Biz and Bytes, 6(2), 125-131. Google Scholar $\chi^{\nearrow} \quad$ CrossRef

[24] Deshmukh, G. K., Joseph, S., \& Sanskrity, J. (2016). Online shopping in India: An enquiry of consumers world. IOSR Journal of Business and Management (IOSR-JBM), 18(1), 28-33. Google Scholar $\chi^{7}$ CrossRef

[25] India number of annual online shoppers. https://www.statista.com/statistics/1191958/indianumber-of-annual-online-shoppers/. Accessed on September 22,2021.

[26] New Telecom Policy 1999. (n.d.). https://dot.gov.in/new-telecom-policy-1999. Accessed on September 10,2021.

[27] Broadband policy 2004. https://dot.gov.in/broadband-policy-2004. Accessed on September 17, 2021.

[28] National Telecom policy 2012. https://dot.gov.in/sites/default/files/NTP-06.06.2012-final_0.pdf. Accessed on August 3,2021.

[29] National Digital Communications 2018. https://dot.gov.in/sites/default/files/EnglishPolicy-NDCP.pdf. Accessed on September 20, 2021.

[30] Telecom Sector in India: A profile. https://www.trai.gov.in/sites/default/files/201304121052403536675NCAER-Report08june12.pdf. Accessed on September 20, 2021.

[31] TRAI-Annual

Report

2021. https://www.trai.gov.in/sites/default/files/Annaul_Report_02032021_0.pdf. Accessed on August 3,2021 .

[32] Srivastava, L. (2005). Mobile phones and the evolution of social behaviour. Behaviour \& information technology, 24(2), 111-129. 
Google Scholar X

$\underline{\operatorname{CrossRef} X}$

[33] Pinchot, J., Paullet, K., \& Rota, D. (2011). How mobile technology is changing our culture. Journal of Information Systems Applied Research, 4(1), 39-48.

Google Scholar $\chi^{\top} \quad$ CrossRef

[34] PESTLE analysis. https://notesmatic.com/telecom-industry-pestelpestle-analysis/. Accessed on September 18, 2021.

[35] Addo, A. (2013). The adoption of mobile phone: how has it changed us socially?. Issues in Business Management and Economics, 1(3), 47-60.

Google Scholar X

CrossRef

[36] Gladden, D. J. (2018). The effects of smartphones on social lives: how they affect our social interactions and attitudes. OTS Master's Level Projects \& Papers. 586.

Google Scholar $\chi^{\nearrow} \quad$ CrossRef

[37] India Smartphone penetration rate. https://www.statista.com/statistics/1229799/indiasmartphone-penetration-rate/. Accessed on September $12,2021$.

[38] Digital transition in India. https://indianexpress.com/article/education/india-did-well-intransition-to-digital-learning-oxford-report-7264765/. Accessed on September 10,2021.

[39] Role of telecom sector in e-governance. https://blog.ipleaders.in/role-e-governance-digital-indiaempowering-indiancitizens/\#Role_of_telecom_sector_in_implementation_and_sustenance_of_e-Governance. Accessed on September 17,2021

[40] India telemedicine market size. https://www.statista.com/statistics/1174720/india-telemedicinemarket-size/. Accessed on September 18,2021.

[41] E-waste from toxic to green. https://unfccc.int/mfc2015/e-waste-from-toxic-to-green/. Accessed on September 18,2021.

[42] E-waste management. https://www.teriin.org/article/e-waste-management-india-challenges-andopportunities. Accessed on September 18,2021. 